\title{
Analysis Of The Performance East Circle Road Of Sidoarjo
}

\author{
Muhammad Ayung Tama*, M. Ikhsan Setiawan, Sapto Budi Wasono
}

Department of Civil Engineering, Faculty of Engineering, Narotama University, Indonesia

*Corresponding author e-mail: ayung0706@gmail.com

Manuscript received 23 Feb 2021; revised 2 March. 2021; accepted 15 March 2021. Date of publication 2 April 2021

\begin{abstract}
Along with the increasing number of the population of Sidoarjo, this has an i mpact on traffic volume, it occurs on the road of Gedangan roads to Buduran, therefore carried out the transfer of road access to the East Ring Road with specialized for heavy vehicles, due to the transfer of the road, it is necessary to perform the analysis of the East circumference road performance. The research aims to determine the magnitude of the influence of heavy vehicle volumes on the road performance of the East Ring road. The performance Of the east circumference traffic by counting the Level Of Service (LOS) and calculating the volume Of the vehicle compared to the road capacity (degree Of saturation). Traffic volume Data surveyed for 2 days (6 and 10 August 2020), for 6 hours per day at $06.00-08.00,12.00-$ 14.00 , and $16.00-18.00$. The analysis of road performance is using the Manual road Capacity (MKJI) method with a degree of saturation (DS) as the main indicator of road performance. The results of the analysis showed the performance of the road on the condition of the excitation point 1 the value of saturation of 0.61 and in point 2 of the value of saturation 0.97 and the result of service level of roadway 1 is $\mathrm{C}$ (steady current speed and motion-controlled vehicles) and in point 2 is $\mathrm{E}$ (current unstable speed sometimes stalled close request of capacity).
\end{abstract}

Keywords: East circumference, Sidoarjo, Indonesia Road Capacity (MKJI).

\section{Introduction}

East Circle Sidoarjo is vital to access that is part of the whole ring road that circles the city of Sidoarjo and serves as an alternative way within the city. The road also plays a role to divert and facilitate the flow of traffic that crosses the city of Sidoarjo. The development that occurs in the city of Sidoarjo must certainly be in a good traffic management system and support infrastructure [1].

East Ring Road Sidoarjo According to its function is classified as a primary arterial road, i.e. the road that serves the main transport with the characteristics of a long-distance journey of high average speed and the number of entrances is limited as efficiently as possible, with the role of distribution service services for urban communities. The criteria on the primary arterial road are that the road is designed based on the lowest plan speed of 60 kilometers per hour based on the government regulation RI number 34 the year 2006. Minimum road width 11 meters[2].

This research aims to know the magnitude of the influence of heavy vehicle volume to the performance of the East Ring Road (East Drive), for the city of Sidoarjo certainly very much expect the city of Sidoarjo to be growing but still comfortable to be in the community in the city of Sidoarjo. Therefore, the city of Sidoarjo should still prioritize the smooth transportation that can certainly be done by implementing the transportation system and the appropriate traffic settings.[3].

The research was conducted on the East Ring road by collecting primary data and secondary data, primary data include road geometric data, side barriers, and traffic volume, while the secondary data include research location data and the population of Sidoarjo Regency according to the Indonesian population census in 2018, to solve this problem, planned traffic management is required so that the solution at one point will not cause problems at other points. To plan this traffic management, it is important to know the behavior of traffic characteristics such as volume, speed, and density. By knowing the volume and speed of a road segment, it can be obtained the performance value of the road.[2].

\section{Literature Review}

\subsection{Road Characteristics}

The main characteristic of the road will affect the capacity and performance of roads if the traffic is being burdened below. The characteristics used in the calculation procedure in this manual can be directly or indirectly. Most of them have also been known and used in other road capacity manuals. However, the influence is different from those in Indonesia.[4] 


\subsection{Geometric Conditions}

Geometric roads are one of the main characteristics of the road that will affect the capacity and performance of roads if burdened traffic. In Indonesia Road capacity Manual (MKJI) 1997[5], among which is included in the geometry of the road as follows :

1. Road type: Different types of roads will show different performance on certain traffic loading, for example, divided and undivided roads, one-way roads. Types of urban roads listed in Manual Road capacity Indonesia MKJI 1997 are as follows :

a. A two-way two-lane path without median (2/2 UD)

b. Two-way four-lane path

1) Undivided (without median) (4/2 UD)

2) Divided (with median) (4/2 D)

c. Two-way Split-Lane Street (6/2 D)

d. One-Way road (1-3/1)

2. Traffic path width: Free current speed and capacity increases with a wide increase in the traffic path. According to Sukirman's View (1994), The traffic lane is the entire road section that is reserved for vehicular traffic. The width of the traffic path is the most defining part of the road crossing width.

3. Shoulder/Curb: As the boundary between traffic paths and sidewalks is very influential on the impact of roadside barriers on capacity and speed. The road capacity with the Curb is smaller than the shoulder road. Further capacity decreases if there is a fixed barrier near the edge of the traffic path, depending on whether the road has a curb or shoulder.

4. Presence or absence of a median, well-planned median increases capacity

\subsection{Side Barriers}

Side barriers, namely roadside activities that can cause conflict and affect the movement of traffic flow and reduce the function of road performance. Pedestrians crossing or walking cause traffic to pause to wait for passing vehicles while pedestrians cross.

There is lost time due to stop and wait, causing a reduced road capacity due to increased travel time for a road section. With the market activities around the road, the activity on the road is increasingly higher. In MKJI 1997.

The high level of side barriers also caused many traders who used sidewalks to sell and the existing condition of sidewalks that could not be passed by pedestrians, so that pedestrians prefer to walk on the road shoulder. (Conny Maretia P. Putri, Symposium X FSTPT, 2007) The side barrier level is grouped into five classes as a function of the incidence of side barriers along with the observed road segments.

Table 1. Side Barrier Class

\begin{tabular}{cccc}
\hline $\begin{array}{c}\text { Weighted } \\
\text { frequency of } \\
\text { events (to two } \\
\text { sides of the road }\end{array}$ & Typical conditions & Side Barrier Class \\
\hline$<50$ & $\begin{array}{c}\text { Inland, agricultural or undeveloped, } \\
\text { without activity }\end{array}$ & Very low & VL \\
$50-149$ & Inland several buildings and activities & Low & L \\
beside the road & Medium & M \\
$150-249$ & Local villages, activities, and transport & High & H \\
$250-350$ & The village, some market activities & Very High & VH \\
\hline 350 & Almost cities/markets, trade activities & & \\
\hline Source : [5] & & &
\end{tabular}

Side barriers are particularly influential for the capacity and performance of the road, while the criteria for side barriers are divided into 4 weights:
a. Pedestrians
(weight $=0.5)$
b. Public transport and other vehicles stop
c. Slow vehicles (e.g. Becak, horse carriage)
$($ weight $=1.0)$
(weight $=0.4)$
d. ehicle out of the land next to the road
$($ weight $=0.7)$

\subsection{Flow and traffic composition}

Based on MKJI 1997 the main function of a road is to provide transportation services so that road wearers can safely and comfortably drive. The parameters of traffic flows that are an important factor in traffic planning are volume, speed, and traffic density.[5]

\subsection{Level Of Servis}

Level of Service" is the level of service of a road that describes the quality of a road and is the limit of operating conditions. The level of service of the road indicates the quality of the road measured by several factors, namely speed and time of travel, density, delay, traffic flow and saturation current, and degree of saturation [5].

\subsection{Speed Observation Method}

Vehicle speed can be observed and calculated by moving observer methods. One of the methods developed on how this moving observer is the Moving Car Observer method.

This method is done by collecting data that includes travel time as well as traffic flow both in the direction as well as in opposite directions with observer vehicles.

With this method, you will get the average speed of the vehicle on a track when the moving vehicle is obtained by dividing the length of the path divided by the time the vehicle moves through the line.[5] 


\section{Method}

The research was classified in descriptive research, this study was conducted to give a more detailed picture of a symptom or phenomenon. As a first step is the collection of data needed to support research to get the correct data, this type of data is divided into 2 namely primary data and secondary data. Surveys are conducted for primary data in the form of Total vehicles counting on the East Ring Road, Data on traffic volume surveyed for 2 days ( 6 and 10 August 2020), for 6 hours per day at $06.00-08.00,12.00-14.00$, and 16.00 - 18.00 Moreover, to obtain the data it is necessary a way to collect it. Related to the problem, to obtain traffic volume data is by Manual Count, which is the traffic calculation simply, counting each type of vehicle through an observation point on a road. The calculation, capacity in Manual Road capacity Indonesia 1997 uses traffic volume of three types of vehicles, namely light vehicles (LV), heavy vehicles (HV), and motorcycles (MC). Heavy vehicles include buses and trucks or vehicles with a total wheel of more than 4 pieces. Light vehicles include passenger cars, common forces such as Bemo and taxi, pickups, car boxes, and small trucks. Motorcycling is all kind of a two-wheeled motor vehicle. The survey power required to record traffic volume is 3 (three) people on each road segment with PEN/pencil and paper equipment with a 15minute time pattern and by making bar marks on the table. Secondary data is also used to support the calculation of traffic performance with data on the population of District Sidoarjo in the year 2018.

\subsection{Date Analysis}

Data analysis using The Indonesian Road Capacity Manual (MKJI) method The data collected later in the analysis to obtain the performance of the roadway in serving existing traffic includes:

a. Free Flow Speed

b. Road Capacity

c. Degree of Saturation

1. Free Flow Speed

Free-flow speed formula according to [5]

$F V=(F V o+F V w) x F F V s f x F F V c S$

Where:

$\mathrm{FV}=$ Light vehicle free flow speed in field conditions $(\mathrm{km} / \mathrm{h})$

$\mathrm{FVo}=$ Light vehicle base free flow speed on observed roads $(\mathrm{km} / \mathrm{h})$

$\mathrm{FVw}=$ Speed adjustment for road width $(\mathrm{km} / \mathrm{h})$

FFVsf = Adjustment factor due to side barriers and shoulder width

FFV cs $=$ Adjustment factor for the path function class

2. Road Capacity

Road capacity formula according to [5]

$C=\operatorname{Co} \times F C w \times F C s p \times F C s f(s m p / h)$

Where:

$\mathrm{C}=$ Capacity

$\mathrm{Co}=$ Base capacity (junior/hour)

$\mathrm{FCw}=$ Adjustment factor due to traffic lane width

FCsp $=$ Adjustment factor due to directional separator

FCsf $=$ Adjustment factor due to side obstacles

3. Degree of saturation

Saturation Degree Formula According to

DS $\quad=\frac{Q}{C}$

Where

$\mathrm{DS}=$ Degree of saturation

$\mathrm{Q}=$ Traffic flow (junior/hour)

$\mathrm{C}=$ Capacity (junior/hour)

\section{Results and Discussion}

\subsection{Road Goemetrik Data}

Geometric data is the data that contains geometric conditions from the road segment being researched. This data is the primary data obtained from a survey of road geometric conditions directly. The geometric Data of the Ligkar East Road section is as follows.

1. Geometric condition and road facilities
a. Road type
: Two two-way lanes $(2 / 2 \mathrm{D})$
: Four divided two-way lanes (4/2D)
b. Length of road segment
: $11 \mathrm{Km}$
c. Line Width
: Two lanes of Duarah $\quad=7$
$:$ Four divided two-way lanes $\quad=14$
d. Shoulder Width : Two two-way column L1=2,9 m, L2=2,0 m
e. Tipe alignment
: Four divided two-way lanes $\mathrm{L} 1=2,0 \mathrm{~m}, \mathrm{~L} 2=1,8 \mathrm{~m}$
f. Signs
g. Traffic Signs
: Flat
: There are
: There are
h. Type op pavement
: Asphalt Concrete (AC) 
2. Traffic

The traffic composition that crosses the East Ring Road section is as follows.

a. Motorcycle (MC), a two-or three-wheeled vehicle

b. Lightweight vehicle (LV), a four-wheeled motor vehicle with two-axle is $2.0-3.0 \mathrm{~m}$ (including Oplet passenger vehicle, Microbus, pick up, and small truck)

c. Heavy vehicle (HV), which is a motor vehicle with two axles is more than $3.5 \mathrm{~m}$, usually wheeled more than four (including bus, truck 2 as, truck 3 as, and truck combination)

3. Side Barriers

Side barriers in this study, including :

a. Pedestrian ( PED)

b. Parking and slow vehicles (PSV)

c. Slow moving vehicles (SMV)

\subsection{Traffic Condition}

Traffic flow data is the primary data obtained directly through field observation, this traffic flow observation is done for 2 days yes it is Monday and Thursday on August 6 and August 10, 2020. Observation time is adjusted with the busyness that occurred on the road of East Lroundabout, observations conducted during the peak hours of the assumption is at 06.00-08.00 at the peak of the morning, at 12.00-14.00 on the top of the day, and at 16.00-18.00 at the peak of the afternoon [6].

Observations are done for 2 hours per 15 minutes. Here the traffic flow data at peak hours obtained from the field, for overall traffic flow data can be seen in the appendix.

1. Survey results of traffic flows and side barriers:

Point 1 morning Peak

Table 2. Traffic flow Data point 1 morning Peak

\begin{tabular}{cccccccccc}
\hline Time (WIB) & \multicolumn{3}{c}{ East - West } & \multicolumn{3}{c}{ West - East } & \multicolumn{3}{c}{ Two-way Total } \\
(Kend/h) & \\
& MC & LV & HV & MC & LV & HV & MC & LV & HC \\
\hline $06.00-06.15$ & 441 & 45 & 0 & 237 & 19 & 16 & & & \\
$06.15-06.30$ & 694 & 49 & 0 & 278 & 19 & 13 & & & \\
$06.30-06.45$ & 788 & 51 & 1 & 485 & 16 & 13 & & & \\
$06.45-07.00$ & 709 & 46 & 2 & 457 & 33 & 0 & & & \\
\hline Total & 2632 & 191 & 3 & 1457 & 87 & 42 & 4089 & 278 & 45 \\
\hline $07.00-07.15$ & 706 & 56 & 1 & 548 & 43 & 0 & & & \\
$07.15-07.30$ & 862 & 67 & 0 & 571 & 75 & 0 & & & \\
$07.30-07.45$ & 764 & 79 & 1 & 627 & 73 & 1 & & & \\
$07.45-08.00$ & 701 & 65 & 1 & 721 & 68 & 2 & & 6 \\
\hline Total & 3033 & 267 & 3 & 2467 & 259 & 3 & 5500 & 526 & 6 \\
\hline
\end{tabular}

Source : Survey results in the field

Table 3. Side Barriers point 1 morning peak

\begin{tabular}{|c|c|c|c|c|c|c|}
\hline Waktu (WIB) & PED & PSV & SMV & PED & $\begin{array}{l}\text { Jumlah } \\
\text { PSV }\end{array}$ & SMV \\
\hline $06.00-06.15$ & 3 & 18 & 15 & & & \\
\hline $06.15-06.30$ & 2 & 10 & 12 & & & \\
\hline $06.30-06.45$ & 0 & 8 & 3 & & & \\
\hline $06.45-07.00$ & 2 & 15 & 7 & 7 & 51 & 37 \\
\hline $07.00-07.15$ & 11 & 13 & 12 & & & \\
\hline $07.15-07.30$ & 3 & 6 & 10 & & & \\
\hline $07.30-07.45$ & 6 & 13 & 16 & & & \\
\hline $07.45-08.00$ & 6 & 7 & 14 & 26 & 39 & 42 \\
\hline Jumlah & & & & 33 & 90 & 79 \\
\hline
\end{tabular}

Source : Survey results in the field

Point 2 morning Peak

Table 4. Traffic flow Data point 2 morning Peak

\begin{tabular}{cccccccccc}
\hline \multirow{2}{*}{ Waktu (WIB) } & \multicolumn{3}{c}{ Timur - Barat } & \multicolumn{3}{c}{ Barat - Timur } & \multicolumn{3}{c}{$\begin{array}{c}\text { Total dua arah } \\
\text { ( Kend/jam) }\end{array}$} \\
& MC & LV & HV & MC & LV & HV & MC & LV & HC \\
\hline $06.00-06.15$ & 658 & 44 & 1 & 124 & 40 & 9 & & & \\
$06.15-06.30$ & 771 & 46 & 1 & 175 & 29 & 4 & & & \\
$06.30-06.45$ & 920 & 59 & 1 & 280 & 38 & 0 & & & \\
$06.45-07.00$ & 765 & 51 & 1 & 330 & 45 & 1 & & & \\
\hline Jumlah & 3114 & 200 & 4 & 909 & 152 & 14 & 4023 & 352 & 18 \\
\hline
\end{tabular}




\begin{tabular}{|c|c|c|c|c|c|c|c|c|}
\hline $07.00-07.15$ & 734 & 55 & 1 & 292 & 48 & 2 & & \\
\hline $07.15-07.30$ & 742 & 68 & 1 & 340 & 42 & 2 & & \\
\hline $07.30-07.45$ & 765 & 73 & 2 & 429 & 48 & 1 & & \\
\hline $07.45-08.00$ & 601 & 83 & 2 & 429 & 80 & 2 & & \\
\hline Jumlah & 2842 & 279 & 6 & 1490 & 218 & 4332 & 497 & 13 \\
\hline
\end{tabular}

Source : Survey results in the field

Table 5. Side Barriers point morning peak

\begin{tabular}{ccccccc}
\hline Waktu (WIB) & \multirow{2}{*}{ PED } & PSV & SMV & Jumlah & PSV & SMV \\
\hline $06.00-06.15$ & 1 & 24 & 2 & & & \\
$06.15-06.30$ & 0 & 9 & 2 & & & \\
$06.30-06.45$ & 2 & 6 & 3 & & & \\
$06.45-07.00$ & 2 & 5 & 2 & 5 & 44 & 9 \\
$07.00-07.15$ & 2 & 10 & 4 & & & \\
$07.15-07.30$ & 0 & 6 & 3 & & & \\
$07.30-07.45$ & 0 & 8 & 1 & & & \\
$07.45-08.00$ & 2 & 7 & 0 & 4 & 31 & 8 \\
\hline Jumlah & & & & 9 & 75 & 17 \\
\hline
\end{tabular}

Source : Survey results in the field

\subsection{Free Flow Speed}

- Point 1

Two undivided two-way lanes $(2 / 2 \mathrm{D})$

$\mathrm{Fv}=(44+0) \times 1,00 \times 0,93$

$\mathrm{Fv}=40,92 \mathrm{Km} /$ hours

- Point 2

Four bidirectional columns divided (4/2 UD)

$\mathrm{Fv}=(57+(-1)) \times 1,03 \times 0,93$

$\mathrm{Fv}=41.18 \mathrm{Km} /$ hours

\subsection{Road Capacity}

- Point 1

Two undivided two-way lanes $(2 / 2 \mathrm{D})$

$\mathrm{C}=3100 \times 1,00 \times 1,00 \times 1,0$

$\mathrm{C}=3100 \mathrm{Smp} / \mathrm{hours}$

- Point 2

Four bidirectional columns divided (4/2 UD)

$\mathrm{C}=1700 \times 0,96 \times 1,00 \times 1,00$

$\mathrm{C}=1632 \mathrm{Smp} / \mathrm{hours}$

\subsection{Degres Of Saturation (DS)}

- Point 1

DS $=1908,2 / 3100$

$\mathrm{DS}=0,61$

- Point 2

$\mathrm{DS}=1595,6 / 1632$

$\mathrm{DS}=0.97$

\subsection{Level Of Servis}

- Point 1

Road Service level $=$ C (steady current speed and vehicle motion-controlled)

- $\quad$ Point 2

Road Service level $=$ E (current unstable speed sometimes interrupted demand approaching capacity)

\section{Conclusion}

Based on the results of the Performance Analysis of the East Ring Road in Sidoarjo Regency on Monday and Thursday, the average conditions are as follows:

1. For the year 2020, the results of the survey concluded that the total number of daily traffic is the largest two-way at a point 1 of 1908.2 SMP/hour at 07.00-09.00 $08(\mathrm{gmt}+7)$ and at the point 2 of 1595.6 SMP/hour at 07.00-09.00 $(\mathrm{gmt}+7)$. 
2. the performance of the eastern periphery of Sidoarjo district in existing condition based on the value of the degree of Point 1 is approaching the standard limit of 0.61 where the standard limit set in Indonesia Road capacity Manual (MKJI) 1997 only 0.75 and Point 2 has exceeded the standard limit of 0.97 where the standard limit set in the Indonesian Road capacity Manual (MKJI) 1997 is only 0.75

3. For the results of the level of service that can be from the calculation then the level Of service or Level Of service that can be in the point 1 is $=\mathrm{C}$ (stable current speed and motion-controlled vehicles) and in point 2 is $\mathrm{E}$ (current unstable speed sometimes stalled demand nearing capacity)

4. Conducting socialization or counseling of traffic order in the form of traffic signs or sanctions in order not to cause a potentially infringing deed of traffic and reduce activities besides the road that can obstruct the visibility of the driver and will be able to enlarge the volume and capacity on the road segments

5. H The results of this research can be used as input materials to the city government, related institutions, practitioners and academics both long and short term to maintain the performance

\section{Acknowledgment}

Alhamdulillahi Rabil 'Alamin, the researcher expressed the highest gratitude to Allah SWT for blessings, loves, opportunity, health, and grace to complete this undergraduate research. The title of the research is Analysis of the performance East Circle road of sidoarjo. Submitted as a final requirement in completing a bachelor's degree in Civil Engineering, University Of Narotama.The researcher presents genuine appreciation to Dr. Ir. Koespiadi, M. T as the dean of the University Of Narotama. Also this research would not have been possible without the help, support, and patience of my first counselor, Dr. M. Ikhsan Setiawan,. S.T., M. T for his supervision, advice, and guidance from the early stages of this study as well as gave me an extraordinary experienced over the last few years. Then to his second advisor Sapto Budi Wasono S.T., M. T who has help me patiently to complete this undergraduate research by providing advice, guidance, and correction until the completion of this research.

\section{References}

[1] T. K. Sendow and M. Manoppo, “Analisa Kinerja Ruas Jalan Manado Bypass Tahap I Di Kota Manado,” vol. 3, no. 6, pp. 413-421, 2015.

[2] E. N. Almaut, S. AS, and S. N. Kadarini, "Analisa kapasitas dan kinerja ruas jalan perintis kemerdekaan pontianak," vol. 1, pp. 1-10, 2016.

[3] D. Rahman, Abdul; Astuti, Sri; Rahadiani, “Analisis Kinerja Ruas Jalan,” Dinas Perhub. Kota Depok, 1997.

[4] J. A. . T. Angelina Indri Titirlobi, Lintong Elisabeth, “Analisa Kinerja Ruas Jalan Hasanuddin Kota Manado,” J. Sipil Statik, vol. 4, no. 7, 2016.

[5] Bina Marga, "Mkji 1997," departemen pekerjaan umum, “Manual Kapasitas Jalan Indonesia.” pp. 1-573, 1997.

[6] C. Amali and B. Ramachandran, "Enabling Key Technologies and Emerging Research Challenges Ahead of 5G Networks: An Extensive Survey," JOIV Int. J. Informatics Vis., 2018, doi: 10.30630/joiv.2.3.128. 